
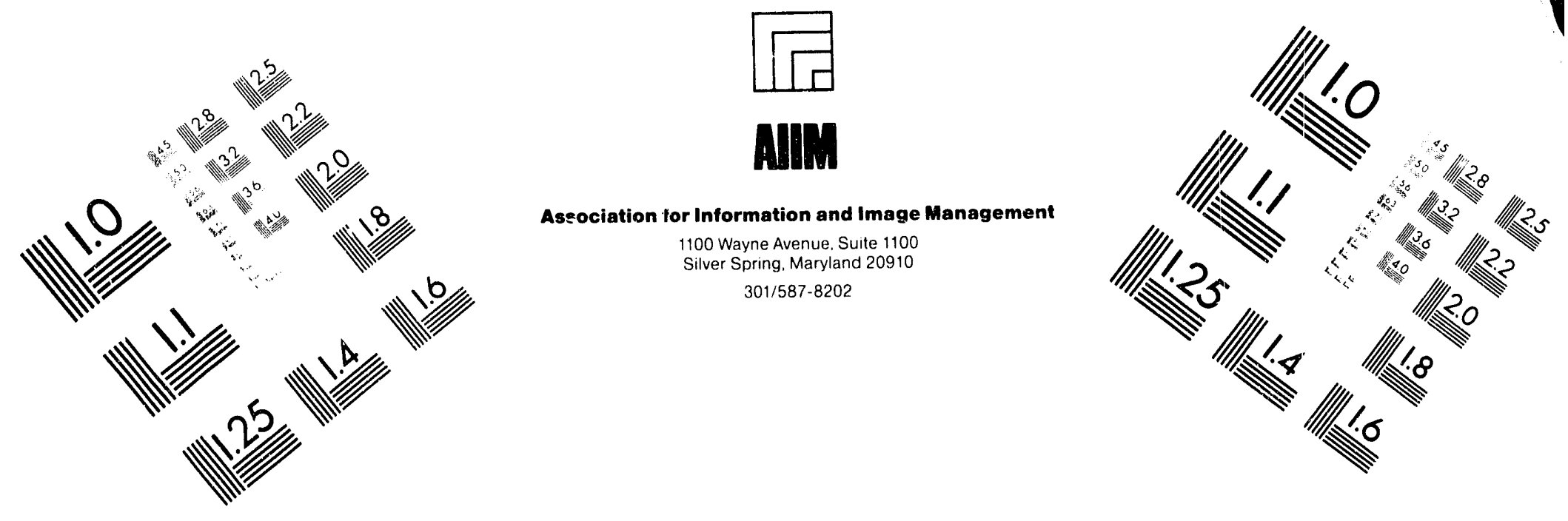

\title{
Centimeter
}

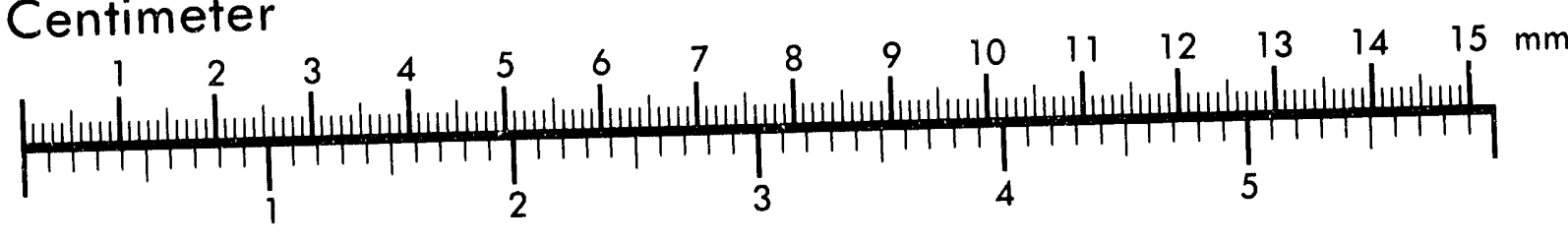
Inches


MANUFACTURED TO AIIM STANDARDS BY APPLIED IMAGE, INC.

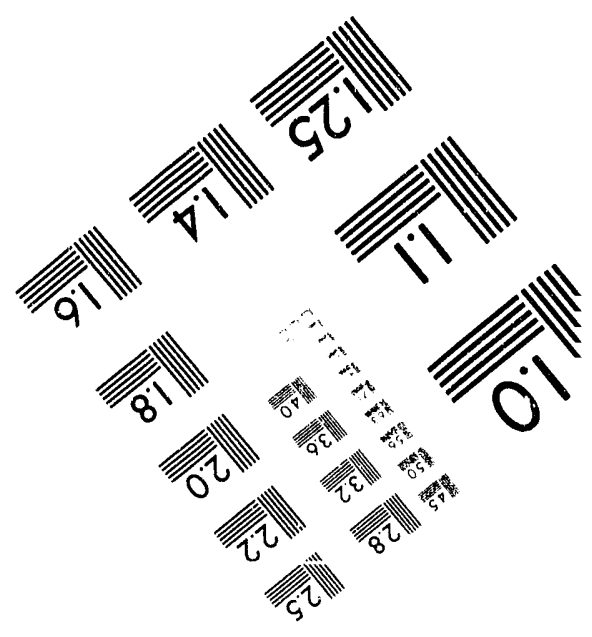



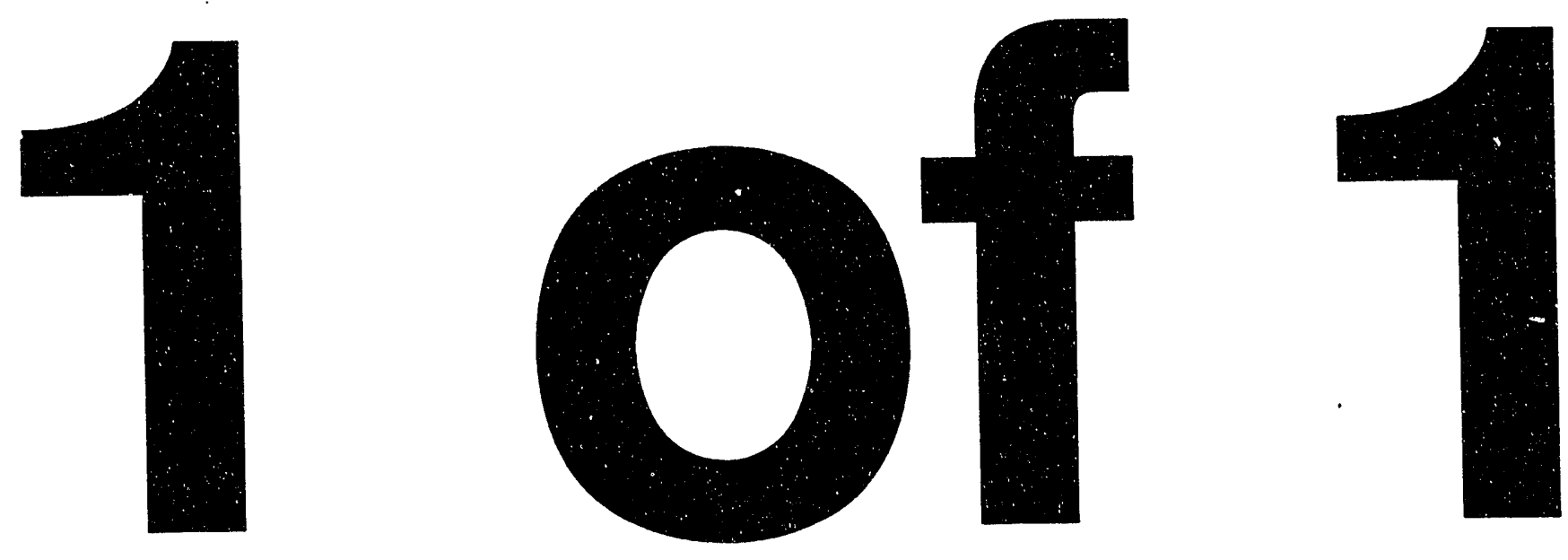


\section{Impact on the Steam Electric Power Industry of Deleting Section 316(a) of the Clean Water Act: Energy and Environmental Impacts}

Environmental Assessment and Information Sciences Division Argonne National Laboratory



Operated by The University of Chicago, under Contract W-31-109-Eng-38, for the MASTER

United States Department of Energy 


\section{Argonne National Laboratory}

Argonne National Laboratory, with facilities in the states of Illinois and Idaho, is owned by the United States govemment, and ope tted by the University of Chicago under the provisions of a contract with ie Department of Energy.

This technical report is a product of Argonne's Er ironmental Assessment and Information Sciences Division. For informatir $n$ on the division's scientific and engineering activities, contact:

Director, Environmental Assessment and Information Sciences Division

Argonne National Laboratory

Argonne, Illinois 60439-4815

Tolephone (708) 252-3759

\section{Disclaimer}

This report was prepared as an account of work sponsored by an agency of the United States Govermment. Neither the United States Govemment nor any agency thereof, nor any of their employees, makes any warranty, express or implied, or assumes any legal liability or responsibility for the accuracy, completeness, or usefulness of any information, apparatus, product, or process disclosed, or represents that its use would not infringe privately owned rights. Reference herein to any specific commercial product, process, or service by trade name, trademark, manufacturer, or otherwise, does not necessarily constitute or imply its endorsement, recommendation, or favoring by the United States Govemment or any agency thereof. The views and opinions of authors expressed herein do not necessarily state or reflect those of the United States Goveınment or any agency thereof.

Avallable to DOE and DOE contractors from the Office of Scientific and Technical Information, P.O. Box 62 , Oak Ridge, TN 37831; prices available from (615) $576-8401$.

Available to the public from the National Technical Information Service, U.S. Department of Commerce, 5285 Port Royal Road, Springfield, VA 22161. 


\section{\% \\ Impact on the Steam Electric Power Industry of Deleting Section 316(a) of the Clean Water Act: Energy and Environmental Impacts}

by J.A. Veil, J.C. VanKuiken, S. Folga, and J.L. Gillette

Environmental Assessmeni and Information Sciences Division,

Argonne National Laboratory, 9700 South Cass Avenue, Argonne, Illinois 60439

January 1993

Work sponsored by United States Department of Energy,

Assistant Secretary for Domestic and International Energy Policy 


\section{CONTENTS}

ACKNOWLEDGMENTS $\ldots \ldots \ldots \ldots \ldots \ldots \ldots \ldots \ldots \ldots \ldots \ldots \ldots \ldots$

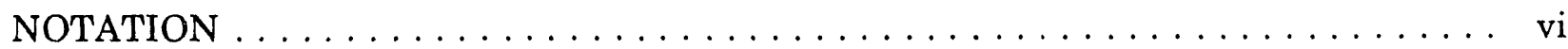

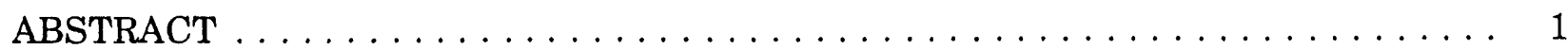

SUMMARY $\ldots \ldots \ldots \ldots \ldots \ldots \ldots \ldots \ldots \ldots \ldots \ldots \ldots \ldots \ldots \ldots \ldots \ldots \ldots$

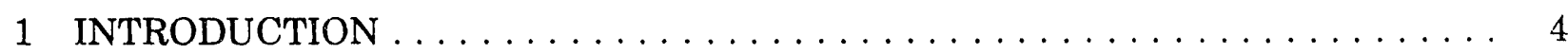

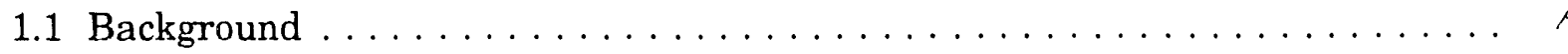



2 ENVIRONMENTAL ISSUES INVOLVING

THE SECTION $316(a)$ VARIANCE $\ldots \ldots \ldots \ldots \ldots \ldots \ldots \ldots \ldots$

2.1 Unique Properties of Heat as a Pollutant $\ldots \ldots \ldots \ldots \ldots \ldots \ldots$

2.2 Environmental Impacts of Once-Through Cooling Systems $\ldots \ldots \ldots \ldots \ldots 6$

2.3 Benefits Resulting from the Section $316(\mathrm{a})$ Variance $\ldots \ldots \ldots \ldots \ldots \ldots$

3 ENERGY IMPACTS OF CONVERSION TO COOLING TOWERS $\ldots \ldots \ldots \ldots .9$

3.1 Description of the Energy Penalty $\ldots \ldots \ldots \ldots \ldots \ldots \ldots \ldots \ldots$

3.2 Magnitude of the Energy Penalty $\ldots \ldots \ldots \ldots \ldots \ldots \ldots \ldots \ldots \ldots \ldots$

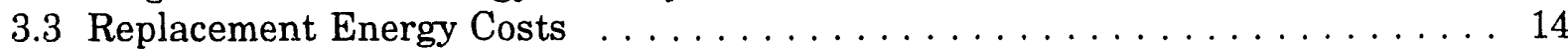

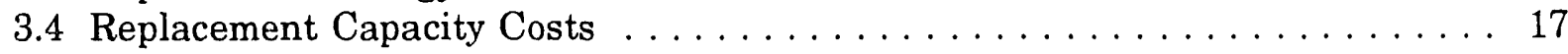

4 ENVIRONMENTAL IMPACTS OF CONVERSION TO

COOLING TOWERS $\ldots \ldots \ldots \ldots \ldots \ldots \ldots \ldots \ldots \ldots \ldots \ldots \ldots \ldots \ldots$





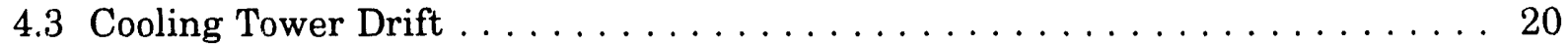

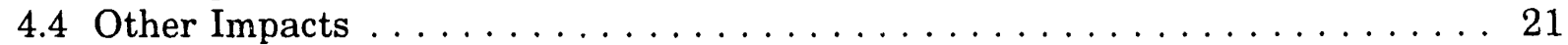

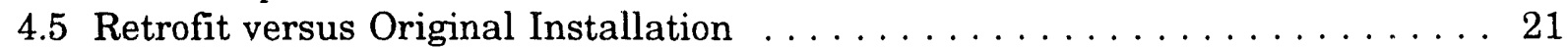

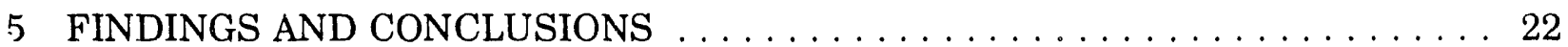

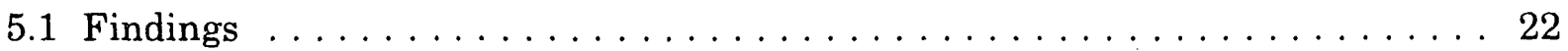

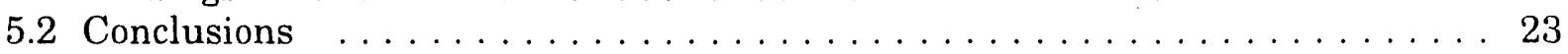

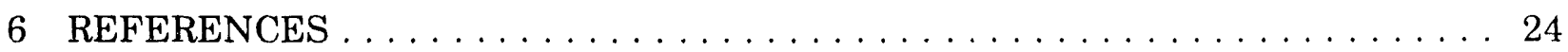

APPENDIX A: Alternate Calculation of Heat Rate Increase $\ldots \ldots \ldots \ldots \ldots 27$

APPENDIX B: Power Pool Designations $\ldots \ldots \ldots \ldots \ldots \ldots \ldots \ldots \ldots \ldots \ldots \ldots$ 


\section{TABLES}

1 Estimated Heat Rate Increases due to Cooling Tower Retrofits at

AEP Power Plants . . . . . . . . . . . . . . . . . . . . . 10

2 Predicted Heat Rate Increases When Once-Through Cooling Systems

Are Replaced with Cooling Towers . . . . . . . . . . . . . . . . . . . 11

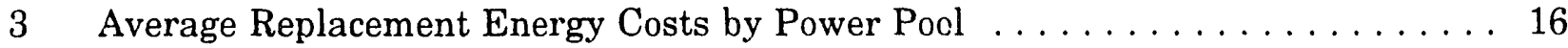

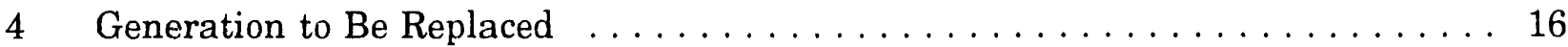

A.1 Results of Intermediate Calculations for Estimated Heat Rate

Change If a Plant with Closed-Cycle Cooling Were Converted to

Once-Through Cooling .......................... 31

A.2 Effect of Cooling System for Pulverized-Coal-Fired Power Plant . . . . . . . . 32

\section{FIGURES}

1 Heat Rate Increase for Pulverized-Coal-Fired Plants . . . . . . . . . . . . . . 13

2 Heat Rate Increase for Nuclear Plants $\ldots \ldots \ldots \ldots \ldots \ldots \ldots$ 


\section{ACKNOWLEDGMENTS}

C. Richard Bozec of Edison Electric Institute and Kristy A.N. Bulliet and Steven J. Koorse of Hunton \& Williams (representing the Utility Water Act Group) were instrumental in coordinating industry review of the draft report. 


\title{
NOTATION
}

\section{ACRONYMS, INITIALISMS, AND ABBREVIATIONS}

\author{
AEP American Electric Power Service Corporation \\ BWR boiling water reactor \\ CWA Jlean Water Act \\ DOE U.S. Department of Energy \\ EEI Edison Electric Institute \\ EPA U.S. Environmental Protection Agency \\ EPRI Electric Power Research Institute \\ NERC North American Electric Reliability Council \\ NRC U.S. Nuclear Regulatory Commission \\ O\&M operations and maintenance \\ PWR pressurized water reactor
}

\section{UNITS OF MEASURE}

Btu British thermal unit(s)

ft foot (feet)

gpm gallon(s) per minute

$\mathrm{kW} \quad$ kilowatt(s)

kWh kilowatt-hour(s)

MW megawatt(s) 


\title{
IMPACT ON THE STEAM ELECTRIC POWER INDUSTRY OF DELETING SECTION 316(a) OF THE CLEAN WATER ACT: ENERGY AND ENVIRONMENTAL IMPACTS
}

\author{
by
}

\author{
J.A. Veil, J.C. VanKuiken, S. Folga, and J.L. Gillette
}

\begin{abstract}
Many power plants discharge large volumes of cooling water. In some cases, the temperature of the discharge exceeds state thermal requirements. Section 316(a) of the Clean Water Act (CWA) allows a thermal discharger to demonstrate that less stringent thermal effluent limitations would still protect aquatic life. About $32 \%$ of the total steam electric generating capacity in the United States operates under Section 316(a) variances. In 1991, the U.S. Senate proposed legislation that would delete Section 316(a) from the CWA. This study, presented in two companion reports, examines how this legislation would affect the steam electric power industry. This report quantitatively and qualitatively evaluates the energy and environmental impacts of deleting the variance. No evidence exists that Section 316(a) variances have caused any widespread environmental problems. Conversion from once-through cooling to cooling towers would result in a loss of plant output of 14.7-23.7 billion kilowatt-hours. The cost to make up the lost energy is estimated at $\$ 12.8-\$ 23.7$ billion (in 1992 dollars). Conversion to cooling towers would increase emission of pollutants to the atmosphere and water loss through evaporation. The second report" describes alternatives available to plants that currently operate under the variance and estimates the national cost of implementing such alternatives. Little justification has been found for removing the 316(a) variance from the CWA.
\end{abstract}

\section{SUMMMARY}

Many power plants discharge large volumes of once-through cooling water. In some cases, the temperature of the discharge exceeds state thermal requirements. Section 316 (a) of the Clean Water Act allows a discharger to demonstrate that the otherwise applicable

* Veil, J.A., 1993, Impact on the Steam Electric Power Industry of Deleting Section 316(a) of the Clean Water Act: Capital Cosis, report ANL/EAIS-4, Argonne National Laboratory, Argonne, III., Jan. 
thermal effluent limits are more stringent than necessary to protect aquatic life and that other less stringent effluent limitations would protect those organisms. About $32 \%$ of the total U.S. generating capacity (189,000 megawatts [MW]) operates under a Section 316(a) variance.

In 1991, U.S. Senate staff members prepared and circulated legislation proposing that Section 316(a) be deleted and that the existing variances be nullified. This study examines how the steam electric power industry would be affected if existing Section 316(a) variances were no longer valid. The results are presented in two companion reports. The other report (Veil 1993) examines the alternatives that a power company that currently operates under the variance could select if the variance were no longer available. It also estimates the national capital cost to continue operating. The conclusion of that portion of this study is that most power companies would install cooling towers and that the national capital costs would range from $\$ 22.7$ to $\$ 24.4$ billion in 1992 dollars.

This report examines the environmental benefits, environmental impacts, and energy costs of eliminating the Section 316(a) variance and converting many power plants from oncethrough cooling systems to cooling towers. A Section 316(a) variance is not an unregulated approval to discharge excess heat. Approval of a variance is preceded by an extensive demonstration that alternative thermal limits will not cause significant harm to the aquatic life in the receiving waters. No evidence has been found that the national program for granting Section 316(a) variances has resulted in widespread environmental problems. Instead, the studies performed to support the requests for variances have contributed to our understanding of aquatic populations and ecology, and the lower operating costs under the variances have lowered electricity costs for ratepayers.

Conversion to cooling towers would result in a lower energy output from the same plant because of increased turbine back pressure and increased auxiliary power demands. This decrease in the energy output is known as an energy penalty. Estimates of the energy penalty for fossil-fuel plants range from 1.1 to $4.6 \%$; for nuclear power plants, estimates range from 1.0 to $5.8 \%$. On the basis of the most representative data, the power industry would need to replace an estimated 14.7-23.7 billion kilowatt-hours of power. The national estimated cost of replacement generation ranges from $\$ 420$ to $\$ 670$ million per year. Over a 20-year period, this need for replacement generation would cost between $\$ 11.4$ and $\$ 18.4$ billion. In addition to the fuel costs for providing the extra energy, some power companies will need to construct new generating capacity. National cost estimates for this additional capacity range from $\$ 1.4$ to $\$ 5.3$ billion in 1992 dollars.

In addition to the energy penalty, the loss of the variance would have several environmental impacts. The need to generate additional power will increase carbon dioxide emissions by an estimated 9 million tons per year. Conversion from once-through cooling systems to cooling towers will result in increased evaporation. Estimates of the quantity of water lost through evaporation range from 1.5 to 2.8 million gallons per minute. Other potential impacts are associated with cooling towers, such as salt drift, fogging or freezing plumes, noise, and general aesthetics. These impacts have not been shown to be significant 
at existing plants, but this conclusion may not hold true if cooling towers are installed at plants that were not designed to use them.

Given the extremely high costs, very minimal benefits, and expected environmental impacts if the Section 316(a) variance were eliminated, little justification has been found for deleting Section 316(a) from the CWA. 


\section{INTRODUCTION}

\subsection{BACKGROUND}

The steam electric power industry uses large volumes of water, primarily for cooling. As a result of the generating process, the water discharged from a power plant is warmer than the water taken in. This temperature difference may be large enough to affect aquatic life. Such thermal discharges are regulated under the Clean Water Act (CWA). However, before discussing these regulations, it will be helpful to review briefly the process of generating electricity.

At nuclear and fossil-fuel plants, electricity is generated by heating purified water to create steam. The steam is used to drive turbines, which in turn drive the generators that produce electricity. After leaving the turbines, the steam passes through a condenser, which has multiple tubes and a large surface area. A large volume of cool water circulates through the tubes, absorbing heat from the steam. As the steam cools and condenses, the temperature of the water rises. In some cases, the change in water temperature can be quite large. The condensers are designed to produce a vacuum at the outlet end of the turbine, which increases the efficiency of the system: the lower the initial temperature of the cooling water, the larger the vacuum that can be produced and the greater the efficiency.

Most power plants use either once-through cooling or closed-cycle cooling. Oncethrough cooling systems withdraw large volumes of water from a river, lake, estuary, or ocean; pump the water through the condenser; and return it to the same or a nearby body of water. Closed-cycle cooling systems ${ }^{1}$ rely on a cooling tower and basin, cooling pond, or cooling lake. Water is withdrawn from the cooling tower basin, pond, or lake; pumped to the condenser; and then returned to the basin, pond, or lake. Because some cooling water evaporates in this process, the concentrations of certain constituents increase. To maintain proper concentrations, a portion of the recirculating water is discharged as "blowdown," and fresh water is added. More information on cooling tower operation is provided in Section 3 of Veil (1993).

The CWA sets limits on thermal discharges. However, Section 316(a) of the CWA provides for variances: a thermal discharger is allowed to demonstrate that applicable thermal effluent limits are more stringent than necessary to protect the organisms in and on the receiving water body and that the other less stringent effluent limitations would protect those organisms. A brief overview of the history of thermal effluent limits and the role of Section 316 is given in Section 1.1 .2 of Veil (1993).

Many power companies relied on the existence of the Section 316 (a) variance in siting and operating their plants. They spent millions of dollars on studies to support requests for such variances. However, as information accumulated from those studies, it was

1 In this report, the terms "closed-cycle cooling" and "cooling tower" are used interchangeably. 
generally recognized that thermal impacts on aquatic biota were less widespread than originally thought. Gradually, the legislative and regulatory focus cn water pollution control shifteu away from thermal issues to control of toxics and nutrients. As a result, the regulated community did not anticipate that the U.S. Senate CWA reauthorization bill, $\mathrm{S} .1081$ (a major legislative proposal introduced in May 1991 by Senate staff members), would contain language that cieleted Section 316.

In addition to deleting the Section 316(a) variance, the May 1991 draft of S. 1081 limited the size of mixing zones ${ }^{2}$ to no more than 1,000 feet, although the thermal plumes of many power plants extend beyond that distance. In December 1991, Senate staff members released an updated version of S. 1081. This bill maintained the deletion of the Section 316 (a) variance and alsc prohibited mixing zones altogether for most pollutants, including temperatire and heat.

\subsection{PURPOSE OF STUDY}

At many power plants, studies were done that demonstrated that once-through cooling water discharges were not harming aquatic communities, and the plants were granted Section 316(a) variances. Other plants are able to comply with state water quality standards at the edge of a mixing zone and do not require variances. However, if S. 1081 were enacted as currently written, not only would existing Section 316(a) variances be voided, but many plants that currently rely on mixing zones in meeting requirements would need to change their operations because such mixing zones would be prohibited as well. This study investigates the impact on the power industry of losing the Section 316(a) variance.

The study was conducted in two parts, which are presented in two companion reports. The other report (Veil 1993) examines the number of plants that would be affected by loss of their Section 316(a) variances, available options, and costs associated with retrofits or changes in plant operations. It concludes that most plants that currently operate under Section 316 (a) variances would be retrofitted with cooling towers if the variances were lost. The estimated national capital cost for the retrofits would be in the range of $\$ 22.7$ to $\$ 24.4$ billion (in 1992 dollars).

This report covers the environınental benefits, adverse environmental impacts, and energy costs of deleting the Section 316 (a) variance.

2 A mixing zone is a limited area surrounding a discharge point in which the effluent mixes with the receiving water; generally, water quality standards must be met at the edge of the mixing zone rather than at the discharge point. 


\section{ENVIRONMENTAL ISSUES INVOLVING THE SECTION 316(a) VARIANCE}

\subsection{UNIQUE PROPERTIES OF HEAT AS A POLLUTANT}

By providing the Section 316(a) variance in the CWA, Congress recognized that heat is a unique type of pollutant. Heat is generally not persistent and does not accumulate in the environment. It is not a toxic or hazardous substance, although all organisms can be harmed by excessive heat. The most compelling reason for giving special treatment to heat as a pollutant is that upon entering a body of water, heat rapidly dissipates to the surrounding water and to the atmosphere. Thus, the impacts of heat are limited to a relatively local zone around the source of heat.

Heat is a natural part of the environment, and solar radiation is a primary driving force in ecosystem dynamics. Thus, in some cases, thermal discharges can actually create a preferred environment for aquatic organisms. For this reason, fishermen frequent areas around power plant discharges during cool weather. Several power companies in the midAtlantic states operate striped bass hatcheries that maintain optimum temperatures yearround by blending the proper mix of ambient water and discharged once-through cooling water. Coutant (1992) reports that record-size striped bass were taken from a Tennessee reservoir, and he conjectures that they grew so large because they had access to cool water from a dam discharge during the summer and warm water from a power plant discharge during the winter. Thus, the fish can migrate to the zone of optimum temperature throughout the year.

\subsection{ENVIRONMENTAL IMPACTS OF ONCE-THROUGH COOLING SYSTEMS}

A variety of potential environmental impacts may be caused by once-through cooling systems. The following are some of the more important ones:

- Thermal plume of heated water:

- Direct temperature impacts,

- Barriers to migration,

- Increased susceptibility to disease as a result of sublethal stress,

- Enhanced populations of nuisance species,

- Decreased diversity of species, and

- Lower dissolved oxygen in discharge; 
- Cold shock;

- Impingement;

- Entrainment;

- Altered current patterns;

- Altered salinity gradients; and

- Discharge of metals.

Some of these impacts are functions of the volume of water passed through a system, not the temperature, and would exist regardless of discharge temperatures. Of the impacts listed, only two - thermal plume impacts and cold shock impacts - are attributable to temperature effects.

Although potential impacts are associated with discharges permitted under Section 316(a) variances, regulatory agencies have the authority and mandate to ensure that the impacts are minimal or nonexistent. A Section 316(a) variance is not trivially granted. To receive the variance, the discharger must demonstrate to the regulatory agency that a discharge that exceeds the otherwise applicable thermal requirements will still protect a balanced, indigenous population in and on the receiving water. The effort required to make this case varies greatly, depending on state requirements and the site-specific potential for impacts. In nearly all cases, however, the demonstration involves extensive evaluation of potential impacts and characterization of local aquatic populations. A regulatory agency can reject a demonstration or ask the discharger to study certain issues in more detail.

If the Section 316(a) variance were deleted, most plants that now operate under the variance would be retrofitted with cooling towers. This approach would eliminate or minimize the impacts listed above. However, for new facilities and some existing facilities, a power company could design a discharge structure to provide rapid mixing of the heated discharge, or it could place the outfall point at a location either vertically or horizontally removed from where sensitive populations of aquatic organisms are likely to be exposed to the thermal plume. Either approach would minimize the once-through cooling impacts. Companies can also institute procedures for gradual reductions in temperature for cases of planned shutdown, to avoid sudden cold shocks. Gradual reduction gives organisms time to acclimate to the ambient temperatures.

The U.S. Environmental Protection Agency (EPA) is evaluating the efficacy of Section 316(a) variances. EF $\downarrow$ officials acknowledge that, at this stage, they have found no indication of widespread environmental problems resulting from discharges of thermal effluent (Reiley 1992). Several cases in which severe problems were found may have been the result of insufficiently stringent permit limits, rather than facility noncompliance with permit limitations. 


\subsection{BENEFITS RESULTING FROM THE SECTION 316(a) VARIANCE}

A valuable benefit of the Section 316(a) variance program has been the opportunity to collect a large amount of data on ecosystem structure, popularion dynamics, and organism response to thermal discharges. (The data were needed for the studies conducted to obtain the variances.) Better yet, the data were site-specific, which allowed greater insight into local situations. As our knowledge of these subjects increased during the 1970s and 1980s, power plant designers have improved structures and operating practices to reduce the environmental impacts of once-through cooling systems. New power plants can now be sited in more benign locations or designed to have fewer cooling systern impacts.

The Section 316(a) variance has saved both the power industry and the ratepayers a substantial amount of money. In its absence, plants would have had to meet more stringent thermal standards or use closed-cycle cooling systems. Little evidence exists that eliminating the Section 316(a) variance would result in significant environmental benefits. 


\section{ENERGY IMPACTS OF CONVERSION TO COOLING TOWERS}

\subsection{DESCRIPTION OF THE ENERGY PENALTY}

If a power plant switches from a once-through cooling system to a cooling tower, there will be an energy penalty: a reduction in the output of electricity from the plant. The reduction occurs for two main reasons. First, the turbine back pressure increases, resulting in less efficient generation. Steam condensers are designed to produce a vacuum at the outlet end of the turbine (that is, to have a low back pressure), and the more complete the vacuum, the greater the generating efficiency. When the temperature of the cooling water increases, a poorer vacuum is created, and less energy can be extracted. Recirculating water from a cooling tower has a higher temperature, on an annual average, than once-through cooling water. Therefore, after switching from once-through cooling to cooling towers, a plant generates less energy from the same amount of fuel.

The second reason for the energy penalty is the additional power required to operate a cooling tower. Although a once-through system pumps a large volume of water, the pumping head (the elevation to which the water must be pumped plus frictional losses) is relatively low. A cooling tower uses a smaller volume of water, but that water is pumped at a higher pressure and to a higher elevation. Consequently, power requirements are substantially higher than they are for a once-through system. In the case of a natural-draft cooling tower, the pump head may be over $90 \mathrm{ft}$. For a mechanical-draft cooling tower, the head typically is much lower, but the total energy needed to operate such a tower is higher, because additional energy is required to power the fans. The water treatment system used for recirculated water will also require electricity for chemical mixers and pumps. Still more electricity will be required to heat, cool, and light the additional buildings associated with the recirculating water system.

\subsection{MAGNITUDE OF THE ENERGY PENALTY}

The performance of a steam electric power plant is generally expressed in terms of the net heat rate, which is the ratio of the amount of heat added to the amount of electrical generation:

Net Heat Rate $(B t u / k W h)=$ Heat Input $(B t u / h) /$ Net Electrical Output $(k W)$.

The net electrical output takes into account losses due to normal in-plant power consumption (e.g., operation of pumps, fans, and transformers). Thus, heat rates are based on the calculation of an overall energy balance. Another way of expressing power plant performance is thermal efficiency. The relationship of heat rate and thermal efficiency is as follows:

Thermal Efficiency (\%) = 3,412.14 / Heat Rate $(B t u / k W h)$. 
As discussed in Section 3.1, plant efficiency will be reduced by the conversion from once-through cooling to cooling towers. However, the available references give different estimates of the magnitude of this loss in efficiency. In one study, the American Electric Power Service Corporation (AEP) reviewed the effects of losing the Section 316(a) variance at nine of its plants (AEP 1992). Table 1 gives the amount of lost capacity for those plants and the percentage increase in the heat rate.

Data on reduced efficiency are also available at a national level. Table 2 presents a summary of the results of the first four studies discussed below. An early study performed by Stone \& Webster (1979) was based on data from power plants that totaled over 72,500 megawatts ( $M W$ ) of steam electric generating capacity. The plants were owned by 50 utilities throughout the United States. In a later study performed for the Edison Electric Institute (EEI), Stone \& Webster (1992) estimated that $54.6 \mathrm{~kW}$ of capacity must be replaced for each megawatt of affected capacity for nuclear plants; the value for fossil-fuel plants is $44.3 \mathrm{~kW} / \mathrm{MW}$. These values translate into an increase in heat rate of about $5.8 \%$ for nuclear plants and about $4.6 \%$ for fossil plants.

United Engineers \& Constructors (1978) prepared a detailed analysis of several hypothetical power plants with various cooling systems at a hypothetical river site. The plants considered were a 1,200-MW pressurized water reactor ( $P W R$ ) nuclear plant, a 1,200-MW boiling water reactor (BWR) nuclear plant, an 800-MW pulverized-coal-fired plant, and a 1,200-MW pulverized-coal-fired plant. This study was performed to complement an earlier United Engineers \& Constructors design study (1974), which evaluated different cooling systems for a 1,000-MW pulverized-coal-fired plant and a 1,000-MW BWR nuclear plant.

TABLE 1 Estimated Heat Rate Increases due to Cooling Tower Retrofits at AEP Power Plants

\begin{tabular}{lcccc}
\hline \multicolumn{1}{c}{ Plant Name } & $\begin{array}{c}\text { Fuel } \\
\text { Type }\end{array}$ & $\begin{array}{c}\text { Nameplate } \\
\text { Capacity } \\
\text { (MW) }\end{array}$ & $\begin{array}{c}\text { Lost } \\
\text { Generation } \\
\text { (MW) }\end{array}$ & $\begin{array}{c}\text { Heat Rate } \\
\text { Increase } \\
(\%)\end{array}$ \\
\hline Cardinal Unit 1 & Fossil & 590 & 10 & 1.1 \\
Conesville Units 1 - 3 & Fossil & 415 & 6 & 1.5 \\
Cook Units 1 \& 2 & Nuclear & 2,110 & 26 & 1.2 \\
Kammer Units 1 - 3 & Fossil & 630 & 13 & 2.1 \\
Kanawha River Units 1 \& 2 & Fossil & 400 & 8 & 2.0 \\
Muskingum River Units 1 - 4 & Fossil & 840 & 16 & 1.9 \\
Picway Unit 5 & Fossil & 100 & 2 & 2.0 \\
Phillip Sporn Units 1 - 5 & Fossil & 1,050 & 21 & 2.0 \\
Tanners Creek Units 1 - 4 & Fossil & 995 & 15 & 1.5 \\
\hline
\end{tabular}

Source: AEP (1992). 


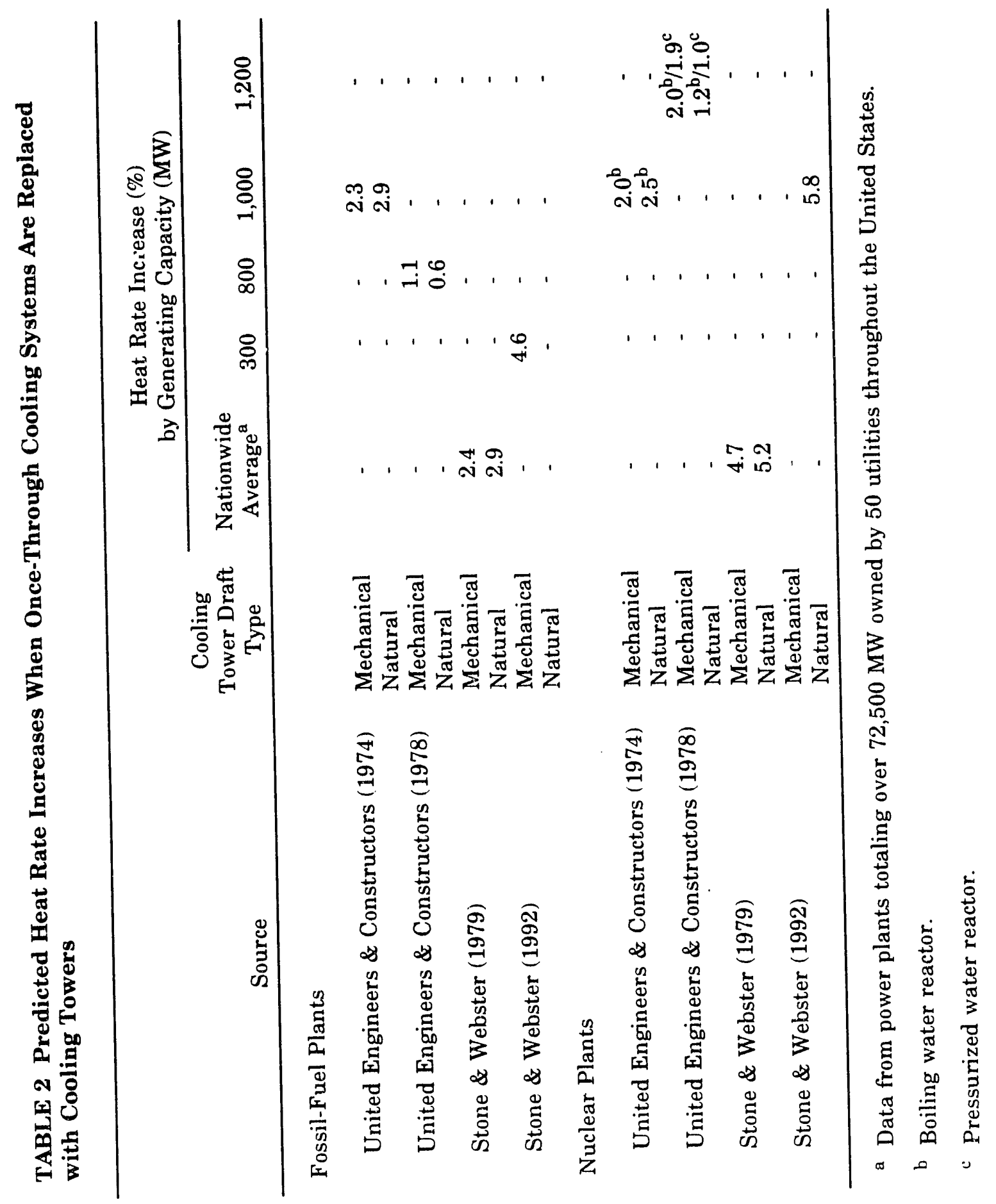


Carter (1991) performed a rough analysis of the impact of requiring cooling towers on all existing fossil and nuclear units that currently use once-through cooling. The additional power requirement to run the cooling system was computed to be about $1 \%$ of plant output, which is equivalent to a $1 \%$ increase in the heat rate. This value is based on the additional power required to operate a cooling tower system. It does not include the effect of increased turbine back pressure; but, given the heat rate values determined by this analysis, including the back-pressure effect would lead to a value consistent with other data discussed here.

Oleson (1971) reviewed the effect of different waste heat rejection technologies on the major design variables of a 1,000-MW nuclear power plant. Replacing a once-through cooling system with a cooling tower system resulted in a $20-\mathrm{MW}$ decrease in the net capacity and a $2 \%$ increase in the heat rate.

For this report, an independent estimate of the heat rate increase was derived by using information from design guidance for a pulverized-coal-fired plant and for a nuclear BWR (Appendix A). The calculated increases are $2.5 \%$ for fossil-fuel, subcritical steam operation; $2.2 \%$ for fossil-fuel supercritical steam operation; and $2.8 \%$ for a BWR nuclear power plant.

Figures 1 and 2 display the various estimates of the heat rate increase that would result from conversion to cooling towers from once-through cooling. Figure 1 gives data for fossil-fuel plants with mechanical-draft cooling towers; Figure 2 gives data for nuclear plants with natural-draft cooling towers. Data are shown for only one type of cooling tower for each type of plant because a review of steam electric plants constructed from 1966 to 1989 showed that these were the technologies of choice for the two plant types (Stone \& Webster 1992). The estimates by Carter (1991) and Stone \& Webster (1979) are plotted as constants across the various megawattage values, because both estimates are based on aggregate data from a variety of plants.

For fossil-fuel plants, most of the data for the heat rate increase are clustered in a band between 1.0 and $2.5 \%$. However, the increase in heat rate developed by Stone \& Webster (1992) is somewhat higher than the others cited. The primary reason for the discrepancy is that Stone \& Webster used a different calculation procedure, which analyzed temperature conditions on a bimonthly basis (to account for differential turbine performance over the year) instead of an annual aggregate basis. Although that approach is valid, the higher heat rate values reported by Stone \& Webster (1992) were not used to estimate national costs in order to provide a more conservative estimate.

For nuclear power plants, the results show greater variability, ranging between 1 and $5.8 \%$. The data points are not as clearly clustered in a narrow range. Thus, it is more difficult to select a range of values that is representative of generalized conditions. The values from the two Stone \& Webster studies $(1979,1992)$ are considerably higher than the other results cited. As discussed above, the discrepancy results from Stone \& Webster's methodology, which emphasized site-specific rather than generalized conditions. At the lower 


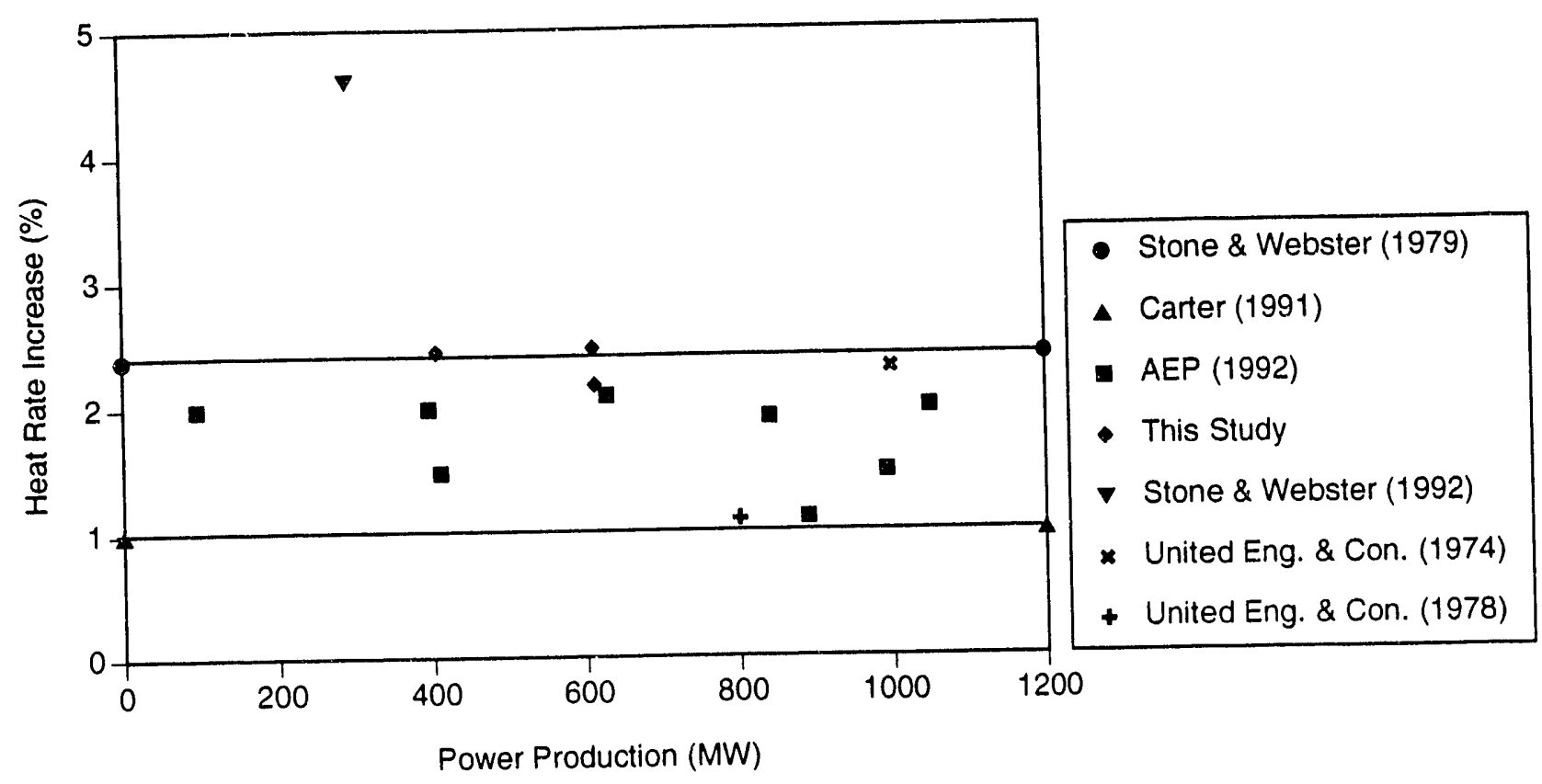

FIGURE 1 Heat Rate Increase for Pulverized-Coal-Fired Plants (values from Carter 1991 and Stone \& Webster 1979 are based on aggregate data)

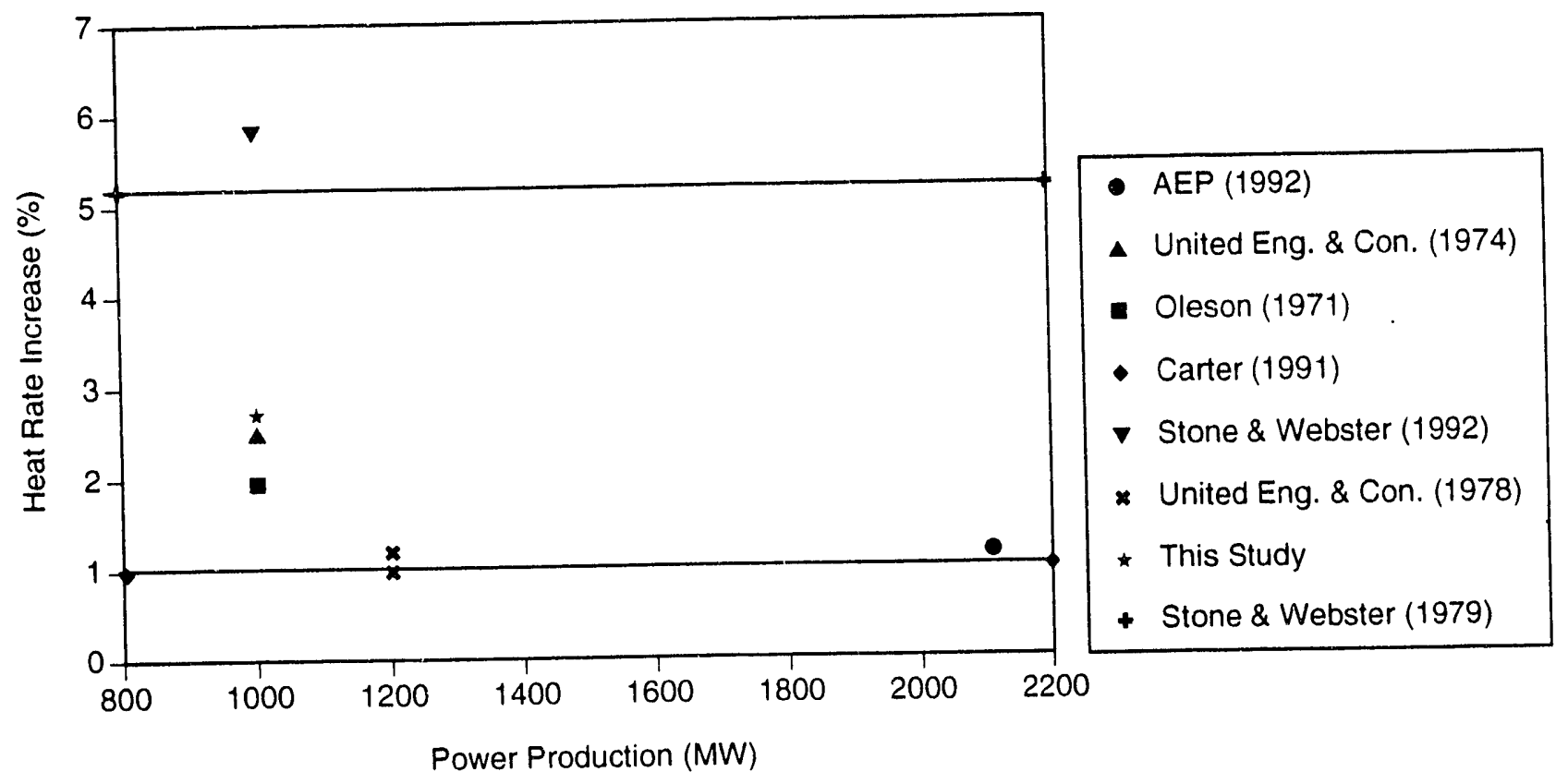

FIGURE 2 Heat Rate Increase for Nuclear Plants (values from Carter 1991 and Stone \& Webster 1979 are based on aggregate data) 
end of the range is the $1 \%$ value from Carter (1991), which, as noted previously, represents only the increase in electrical consumption due to the change in pumping requirements and fan usage; it does not include the effects of increased turbine back pressure.

Other values near the lower end of the range are the 1978 results from United Engineers \& Constructors and the 1992 results for American Electric Power's Cook plant (AEP 1992; Table 1). United Engineers' values are based on an optimized retrofit design, which may not be applied in practical situations because of its high capital cost. The AEP value is based on an order-of-magnitude estimate specific to the Cook plant and therefore may not be representative of the generalized conditions being considered here. On the basis of the data in Figure 2, as qualified above, and the analysis outlined in Appendix A, a range of 2 to $3 \%$ was selected for the estimated decrease in net electrical power that would be experienced if existing nuclear power plants were converted from once-through cooling to cooling towers.

In general, it would be expected that the heat rate increase resulting from conversion to cooling towers would be greater for nuclear facilities, for two reasons. First, nuclear power plants are more sensitive to the increased turbine back pressure associated with cooling towers (Section 3.1). They require a greater quantity of lower pressure steam to produce the same electrical output as a fossil-fuel plant. Because lower pressure steam is used, a greater fraction of the overall steam turbine work is produced from the lowest pressure turbine stage. Thus, any change in the turbine back pressure has a greater effect on the generating capacity of a nuclear plant than on the capacity of a fossil-fuel plant.

Second, nuclear power plants reject more heat to the cooling system per kilowatt of output. About $36 \%$ of the energy used by a fossil-fuel plant is converted to electrical energy, while about $15 \%$ of the energy is lost to the atmosphere through the smokestack and within the plant; thus, only $49 \%$ of the input energy becomes waste heat that must be dissipated by the cooling system. In a nuclear plant, by contrast, only $31 \%$ of the energy used by the plant becomes electricity. Given that $4 \%$ is lost in the plant, about $65 \%$ of the input energy must be dissipated as waste heat. Therefore, more cooling water must be circulated, which requires greater pumping power (and greater fan power in the case of mechanical-draft cooling towers). As a result, the net generating capability decreases and the heat rate increases.

\subsection{REPLACEMENT ENERGY COSTS}

The cost of making up for the energy penalty has two components: the cost of generating replacement energy and the capital cost of building new generating capacity. The costs of generating replacement energy can be estimated from an analysis conducted for the U.S. Nuclear Regulatory Commission (NRC) (VanKuiken et al. 1992). The purpose of the analysis was to provide the NRC with realistic estimates of replacement energy costs for short-term shutdowns of nuclear generating facilities. The information was developed principally for use in regulatory impact analysis of retrofits or safety modifications that might necessitate short-term reactor outages. 
While that work emphasized nuclear facilities and short-term outages, the results can be used in examining the broader implications of efficiency losses caused by cooling tower retrofits. It would be expected that replacement generation would be provided from sources throughout each affected power pool or utility system. The contributions would be provided in small increments from the most economical generating units that were available for additional dispatching. The replacement energy costs developed in VanKuiken et al. (1992) directly addressed this issue by using dispatching simulations that recognized cost, performance, and availability parameters for each generating facility, as well as detailed system load representations.

Replacement energy costs were developed in VanKuiken et al. (1992) for each of 112 reactors located in 20 of the 26 power pools ${ }^{3}$ that constitute the U.S. electrical utility grid. The 20 power pools provide more than adequate coverage for developing cost estimates that are representative of U.S. averages. Minor adjustments to the reported costs are required because the published results include a cost credit for normal nuclear fuel charges and operations and maintenance (O\&M) charges (both of which would be av' ided during shortterm reactor shutdown periods). Such cost credits are not appropriate for evaluating the replacement energy costs due to efficiency losses. The necessary adjustments have been made in the tables and analyses that follow.

Table 3 shows the average cost of replacement generation by power pool. The variation in costs reflects the different generator types and fuel types available to provide replacement generation (in addition to serving existing load requirements) for each power pool. The results also reflect regional differences in fuel prices. The ultinate choice of replacement capacity (discussed below) does not significantly affect the replacement energy costs, because replacement energy would be produced by the industry as a whole rather than by a dedicated generating unit.

The total generation to be replaced and the amount of generation to be replaced in each power pool must be determined before applying the costs from Table 3 . Because the locations of specific units affected by Section 316(a) variances were not available for this analysis, the regional distribution was assumed to be equal to the proportions of historical generation (North American Electric Reliability Council [NERC] 1991b, 1990 data) for each power pool. The total generation to be replaced can be estimated by applying historical capacity factors and energy penalties to the capacity of nuclear and fossil units influenced by the variances. Table 4 displays the replacement generation estimates; the total is 14.7-23.7 billion $\mathrm{kWh}$.

3 Power pools represent groups of utility systems that participate in coordinated operations, either through centrally dispatched control systems or through less formal economic capacity and energy exchanges. Appendix B contains an index of the power pool numbers referred to in this report. 
TABLE 3 Average Replacement Energy Costs by Power Pool

\begin{tabular}{|c|c|c|}
\hline $\begin{array}{c}\text { Power } \\
\text { Pool }^{\mathrm{a}}\end{array}$ & $\begin{array}{c}\text { Average } \\
\text { Replacement } \\
\text { Energy Cost } \\
{\text { (mills } / \mathrm{kWh})^{\mathrm{c}}}^{\mathrm{c}} \\
\end{array}$ & $\begin{array}{c}\text { Percentage of Total } \\
\text { Generation for All } \\
\text { Power Pools }\end{array}$ \\
\hline 1 & 19.1 & 5.16 \\
\hline 2 & 23.1 & 2.98 \\
\hline 4 & 29.3 & 3.28 \\
\hline 5-6 & 27.4 & 8.16 \\
\hline 7 & 30.5 & 7.88 \\
\hline 8 & 32.1 & 3.24 \\
\hline $9-10$ & 21.1 & 2.64 \\
\hline 11 & 26.3 & 1.69 \\
\hline 12 & 17.3 & 5.21 \\
\hline 14 & 33.5 & 4.04 \\
\hline 15 & 41.1 & 5.46 \\
\hline 16 & 36.4 & 4.67 \\
\hline 17 & 27.7 & 6.72 \\
\hline 18 & 21.3 & 4.55 \\
\hline 19 & 27.2 & 7.81 \\
\hline 20 & 23.9 & 4.60 \\
\hline 22 & 21.9 & 2.24 \\
\hline 25 & 23.4 & 9.15 \\
\hline 26 & 30.1 & 2.84 \\
\hline 27 & 42.3 & 7.68 \\
\hline
\end{tabular}

a Numbers omitted from this table are either no longer used or were not included in the previous study of replacement energy costs (VanKuiken et al. 1992).

b 1991 dollars.

c 1 mill $=0.1$ cent.

Sources: NERC (1991a), VanKuiken et al. (1992).

\section{TABLE 4 Generation to Be Replaced}

\begin{tabular}{lcccc}
\hline $\begin{array}{c}\text { Fuel } \\
\text { Category }\end{array}$ & $\begin{array}{c}\text { Capacity of Plants } \\
\text { that Operate under } \\
\text { Section 316(a) } \\
\text { Variances (MW) }\end{array}$ & $\begin{array}{c}\text { Annual } \\
\text { Capacity } \\
\text { Factor }(\%)\end{array}$ & $\begin{array}{c}\text { Energy } \\
\text { Penalty }(\%)\end{array}$ & $\begin{array}{c}\text { Replacement } \\
\text { Energy } \\
\text { Requirement } \\
\left(10^{9} \mathrm{kWh}\right)\end{array}$ \\
\hline Nuclear & 43,000 & 66.3 & $2.0-3.0$ & $5.0-7.5$ \\
Fossil & 146,000 & 50.7 & $1.5-2.5$ & $9.7-16.2$ \\
\hline
\end{tabular}


A weighted average cost for replacement generation was obtained by multiplying the replacement cost per kilowatt-hour for each power pool by the relative fraction of generation from that power pool and then averaging. The fractions are shown in Table 3. The weighted average produced by this approach is $28.3 \mathrm{mills} / \mathrm{kWh}(1 \mathrm{mill}=0.1 \mathrm{cent})$.

Applying the weighted average to the total generation to be replaced (14.7-23.7 billion $\mathrm{kWh}$ ) yields a total cost estimate of $\$ 420-\$ 670$ million per year. Over 20 years, the levelized value of these costs would be approximately $\$ 570-\$ 920$ million per year (\$11.4-\$18.4 billion total). This estimate assumes zero real escalation in fuel and variable O\&M costs, a discount rate of $10.5 \%$, and an annual inflation rate of $4 \%$.

\subsection{REPLACEMENT CAPACITY COSTS}

Accurate estimates of capacity replacement costs are typically derived from optimization simulations of long-term capacity expansion decisions. Capacity expansion analysis traditionally uses production-cost simulations applied to long planning horizons to determine the least-cost strategy (including choices among alternative generating technologies and timing options) for adding new capacity to meet system loads and reliability criteria. However, because the level of effort and detail for such an analysis was beyond the scope of this project, a simplified approach was adopted to approximate the costs of constructing replacement capacity.

On the basis of the information in Tables 3 and 4, the need for replacement capacity is estimated to range from 52 to $452 \mathrm{MW}$ per power pool. The lower value was obtained for the smallest power pool (Pool 11) by using the lower estimates of the energy penalty $(2.0 \%$ for nuclear and $1.5 \%$ for fossil-fuel units). The higher value was derived by applying the higher estimates of the energy penalty $(3.0 \%$ for nuclear and $2.5 \%$ for fossil-fuel units) to the largest power pool (Pool 25).

Because capacity planning is often performed at the utility level rather than at the power pool level, the unit sizes required for replacement capacity would be even smaller than the 52-452-MW range. On the one hand, the small increments of required capacity would dictate that replacement capacity costs be characterized by the capital costs for combustion turbines. On the other hand, it can also be argued that utilities could upgrade the sizes of planned units that are not yet under construction. If this approach were taken, incremental capital costs for coal steam units might be more representative.

In reality, responses to the projected efficiency losses by utilities in the United States would probably span the entire range of capacity options. Each utility would base its decision on existing reserve margins, construction schedules for planned facilities, fuel prices, load projections, and the availability of power purchases from interconnected systems. To simplify these issues, a range of replacement capacity costs was established. At the low end of this range is the cost for a 50-MW combustion turbine unit: approximately $\$ 450 / \mathrm{kW}$. At the high end is the cost for upgrading a 500-MW coal unit to $600 \mathrm{MW}$ : approximately $\$ 1,080$ /incremental kW (Electric Power Research Institute [EPRI] 1988, 1989). 
By applying the cost range of $\$ 450-1,080 / \mathrm{kW}$ to the range of total capacity needs (3,050-4,940 MW for the United States), replacement capacity costs can be estimated as $\$ 1.4-\$ 5.3$ billion. This range may underestimate the total replacement capacity cost because it does not account for the replacement capacity that would be needed if utilities were to accelerate the retirement of older units in response to the deletion of Section 316(a).

Other factors that would contribute to increased cost if a plant were retrofitted with cooling towers include the length of time that a plant must be taken out of service in order to physically construct and connect the cooling tower, increases in the number of unscheduled outages, and the costs associated with obtaining all the necessary permits to construct a cooling tower. 


\section{ENVIRONMENTAL IMPA: :TS OF CONVERSION TO COOLING TOWERS}

\subsection{INCREASED POWER GENERATI'ON}

As discussed in the previous section, conversion from once-through cooling systems to cooling towers exacts an energy penalty. To make up for the additional energy demands, a power company must barn more fuel. Neither the process of extracting the fuel from the environment nor transporting it to the power plant sitc is environmentally benign. These impacts cannot be quantified easily, tut clearly they are deleterious to the environment. From the standpoint of conservation of nati,ral resources, burning additional fuel for a questionable environmental gain is imprudent..

Each unit of fuel burned would cause additional air emissions. In light of current concerns about global warming, carbon dioxide emissions are of interest. U.S. Department of Energy (DOE) staff prepared an informal computation of the additional carbon dioxide releases and evaporative losses that would occur if all power plants that currently use oncethrough cooling were converted to cooling towers (Carter 1991). This analysis assumed only a $1 \%$ energy penalty, but still resulted in an estimated increase in carbon dioxide emissions of 11.2 million tons per year and an estimated evaporative loss of 3.6 million gallons per minute of water.

However, not all power plants that currently use once-through cooling systems operate under Section $316($ a) variances, so Carter's estimate must be reduced accordingly. His analysis shows that for fossil-fuel plants, $61 \%$ burn coal. $20 \%$ burn natural gas, and $19 \%$ burn oil. After applying these percentages to the 146,000 MW of capacity of fossil-fuel units that operate under variances, and including the 43,000 MW of capacity of nuclear units that operate under variances, the calculations vield a result of about 9 million tons per year of increased carbon dioxide emissions and 2.8 million gallons per minute of additional evaporative loss.

In addition to emission of air pollutants, construction would create additional impacts. For many power companies, the need to supply additional power could not he met with their exusting capacity, so they would have to build new capacity. Constructing any commercial-scale generating unit is an expensive and time-consuming process. In addition, environmental impacts, such as stormwater runoff, are associated with any construction project. Features of site development, such as service roads, parking lots, and pipeline and power line corridors, would result in changes in land use, runoff characteristics, and wildlife habitat.

\subsection{INCREASED WATER CONSUMP'TION}

Another impact from installing a large number of new cooling towers is that more water will be consumed. Cooling towers rely primarily on evaporation to achieve their 
cooling. Once-through cooling systems also cause evaporation by raising the temperature of the thermal plume in the receiving waters. However, little quantitative evidence exists regarding the magnitude of the once-through evaporative effect, because it is widely dispersed and gradual.

In contrast, the evaporation from a cooling tower is evident, quantifiable, and larger than that from a once-through cooling system (NRC 1991). Stone \& Webster (1992) estimates that the total national water consumption would increase by 1.5 million gallons per minute if all once-through plants that operate under Section 316(a) variances were to switch to cooling towers. When Carter's data are adjusted for those once-through plants that operate under variances, as discussed above, the evaporative loss can be estimated at 2.8 million gallons per minute. For comparison, the average flow of the Potomac River near Washington, D.C., is about 5.1 million gallons per minute.

As a result of evaporation, the solids in the recirculating water accumulate. To avoid a luss in heat transfer efficiency, a part of the recirculating water is removed periodically as blowdown. The blowdown may contain priority pollutants or other toxic substances. Discharges of cooling tower blowdown are regulated by the effluent limitations guidelines for the steam electric power industry (40 CFR Part 423). These regulations apply to chlorine and priority pollutants contained in chemicals added for cooling tower maintenance.

In some parts of the country, additional evaporative losses would place a strain on aiready limited water resources. In California and several other western states, drought cor. ditions have continued for several years. Major water rights legislation was considered by Congress in 1992 that would allocate water resources to western consumers. Even the eastern states, where traditionally water has been plentiful, have experienced temporary drought conditions, and it is now recognized that water is not a limitless commodity. Additional consumption of water by cooling towers, without a concomitant environmental benefit, is counterproductive. However, EPRI ( 1991) reports that even in water-short regions, under extreme conditions, a utility may be able to turn to other sources of lower quality water, such as sewage treatment plant effluent, if such sources are available.

\subsection{COOLING TOWER DRIFT}

As air exits a cooling tower, it is saturated with water vapor. It also conveys many small droplets of water, which make up a plume that eventually reaches the ground. This plume is called "cooling tower drift." While the water vapor is pure, the drift still contains all of the contaminants present in the recirculating water. Physical and chemical properties of the drift have the potential to cause localized environmental impacts. Drift is much more of an issue with mechanical-draft towers than with natural-draft towers.

Fogging or icing can occur when the drift encounters humid or freezing conditions. If the cooling tower is located near a road or airport, hazardous conditions can result. Frozen drift can also cover vegetation with a coating of ice, which may damage trees and shrubs. 
In towers that use saltwater or brackish water, the drift may be salty, which could harm vegetation. Even the drift from a tower that uses fresh water can be somewhat salty because of the concentrating effects of evaporation. Drift can also contain concentrated biocides that were present in the recirculating water. However, the authors of a report prepared for the NRC (1991) reviewed the literature and concluded that no significant impacts from drift on agricultural crops or natural vegetation had occurred from nuclear plants with cooling towers or from a fossil-fuel plant that uses brackish water and a cooling tower. Nevertheless, it is possible that site-specific problems might occur.

\subsection{OTHER IMPACTS}

- Noise. Mechanical-draft cooling towers are noisy because they use multiple fans. An NRC report (1991) found that noise impacts are small and tend not to be noticed by the public.

- Aesthetics. Natural-draft cooling towers are quite large and visually imposing. Such large structures present aesthetic problems. Generally, power plants large enough to warrant natural-draft towers are located in isolated areas where the aesthetics are not as critical as in an urban or suburban setting.

- Sludge. Silt in the makeup water and dust and debris that fall from the sky into the tower basin accumulate as sludge, which must periodically be removed, creating an additional disposal issue.

\subsection{RETROFIT VERSUS ORIGINAL INSTALLATION}

Most of the environmental impacts discussed above are not significant at plants where cooling towers have been designed and built as part of the original installation. This conclusion would not hold true if a large number of new cooling towers were installed as retrofits. Many of the plants that currently operate under Section 316(a) variances are older plants located in or near urban or suburban areas. Environmental impacts like drift or noise, which are mitigated by the large buffer zones around plants in rural locations, could present serious problems for urban locations. For example, some of the plants operated by Baltimore Gas and Electric in Baltimore are close to interstate highways and bridges or are near the final flight approach paths to airports. Freezing or fogging from cooling tower plumes could present a safety hazard. Zoning concerns in populated areas would likely place greater restrictions on the appearance and noise level of cooling towers.

The water consumption issue may be the most critical concern for a retrofitted cooling tower. If a plant is designed to consume a certain volume of water through evaporation, then that volume is factored in from the time a plant is built. However, if a cooling tower is added later, adequate water resources may not be available to accommodate the increased demand. 


\section{FINDINGS AND CONCLUSIONS}

This report considers the environmental benefits, environmental impacts, and energy costs of eliminating the Section 316(a) variance in the CWA. The findings and conclusions are presented below.

\subsection{FINDINGS}

- Heat is a natural part of the environment and, under certain circumstances, heated waters may represent a preferred habitat. Excessive heat can cause problems, but they are site-specific and usually localized.

- The Section 316(a) variance is not an unregulated approval to discharge excess heat. Granting of a variance is preceded by an extensive demonstration that less stringent thermal limits will not cause significant harm to aquatic life in the receiving waters. This demonstration must be approved by regulatory agencies, and the variance must be renewed every five years.

- No evidence has been found that the national program for granting Section 316(a) variances has resulted in widespread environmental problems. Instead, the studies have contributed to our understanding of aquatic populations and ecology, and the variances have allowed ratepayers to enjoy lower electricity costs.

- If the Section 316(a) variance were removed from the Clean Water Act, many power companies would retrofit existing once-through cooling systems with cooling towers. The capital costs of installing the towers is very large (Veil 1993). Conversion to cooling towers would also result in a lower energy output from the same plant because of increased turbine back pressure and increased auxiliary power demands. This differential is known as the energy penalty.

- Based on a literature review and on calculations performed in this report, estimates of the energy penalty for fossil-fuel plants range from 1.1 to $4.6 \%$, with most of the data falling in the range of 1.5 to $2.5 \%$. The energy penalty for nuclear plants ranges from 1.0 to $5.8 \%$, with the most relevant data falling in the range of 2 to $3 \%$.

- Any power company faced with a cooling tower retrofit would need to make up the energy lost as a result of the energy penalty. If the 
smaller ranges described for the energy penalty are used, an estimated 14.7 to 23.7 billion $\mathrm{kWh}$ would need to be replaced.

- If an average replacement cost of $\$ 28.3 \mathrm{million} / \mathrm{kWh}$ is used, the national estimated cost of replacement generation ranges from $\$ 420$ to $\$ 670$ million per year. Over a 20 -year period, the estimated cost is $\$ 11.4$ to $\$ 18.4$ billion, assuming zero real escalation in fuel and variable O\&M costs, a discount rate of $10.5 \%$, and an annual inflation rate of $4 \%$. All figures are expressed in 1992 dollars. This estimate compares reasonably to the estimate of present value cost for additional fuel (over a 20-year period) given in Stone \& Webster (1992) of $\$ 9.4$ billion in 1992 dollars.

- In addition to the fuel costs for providing the extra energy, some power companies would need to construct new generating capacity. National cost estimates for this additional capacity range from $\$ 1.4$ to $\$ 5.3$ billion in 1992 dollars. Stone \& Webster's (1992) present value estimate for capital cost of replacement units is $\$ 2.2$ billion in 1992 dollars.

- The need to generate additional power would increase carbon dioxide emissions by an estimated 9 million tons per year. Construction of new generating units would cause environmental impacts such as changes in land use, runoff characteristics, and wildlife habitat.

- Conversion from once-through cooling systems to cooling towers would result in increased evaporation. Estimates of the quantity of water lost through evaporation range from 1.5 to 2.8 million gallons per minute.

- There are other potential impacts associated with cooling towers, such as salt drift, fogging or freezing plumes, noise, and general aesthetics. Generally, these impacts have not been shown to be significant at existing plants. This conclusion may not hold true if cooling towers are installed as retrofits at plants that were not designed or sited with cooling towers in mind.

\subsection{CONCLUSIONS}

- The Section 316(a) variance program has not caused significant environmental degradation and has resulted in cost savings to ratepayers.

- If the Section 316(a) variance were removed, it is estimated that the national costs to the power industry, and ultimately to the rate 
payers, would be in the range of $\$ 35.5$ to $\$ 48.1$ billion in 1992 dollars. This estimate is the sum of the capital costs for retrofitting plants with cooling towers and building new generating units, plus the increased fuel costs for a 20 -year period. This range bounds the present value cost estimate derived by Stone \& Webster (1992) of $\$ 41.3$ billion in 1992 dollars. Although these numbers are based on solid technical data, they are only estimates. However, even if the true costs are several times lower, the magnitude of the cost is still very large.

- Substantial potential environmental impacts are associated with installation and operation of cooling towers.

- Considering the extremely high costs, very minimal benefits, and new environmental impacts resulting from removal of the Section 316(a) variance, little justification has been found for removing the variance from the CWA. 


\section{REFERENCES}

AEP, 1992, 1992 Clean Water (CWA) Reauthorization - Cost Analysis on the Impact to AEP System of Losing Section 316(a) Thermal Discharge Variance, American Electric Power Service Corporation, Columbus, Ohio, March.

Avallone, E.A., and T. Baumeister, 1987, Marks' Standard Handbook for Mechanical Engineers, 9th ed., McGraw-Hill Book Co., New York, N.Y., pp. 9-54 to 9-57.

Carter, D., 1991, memorandum from Carter (U.S. Department of Energy, Washington, D.C.) to J. Gardner (Edison Electric Institute, Washington D.C.), Sept. 27.

Coutant, C., 1992, Regulation of Thermal Discharges: Maturing Perspectives after Two Decades of Field Studies under Section 316(a), prepared for Edison Electric Institute, Washington, D.C.

CWA, 1972, "Clean Water Act (Federal Water Pollution Control Act)," Public Law 92-500, U.S. Code 33:1251.

DOE, 1983, Energy Technology Characterizations Handbook: Environmental Pollution and Control Factors, report DOE/EP-0093, U.S. Department of Energy, Washington, D.C.

EPRI, 1988, An Evaluation of Integrated-Gasification-Combined-Cycle and Pulverized-CoalFired Steam Plants, report EPRI AP-5950, Electric Power Research Institute, Palo Alto, Calif.

EPRI, 1989, TAG Technical Assessment Guide, Electrical Supply - 1989, report EPRI P-6587-L, Vol. 1, Rev. 6, Electric Power Research Institute, Palo Alto, Calif.

EPRI, 1991, Dry Cooling: Perspectives on Future Needs, report EPRI GS-7446, Electric Power Research Institute, Palo Alto, Calif.

NERC, 1991a, Electricity Supply and Demand, 1991-2000, North American Electric Reliability Council, Princeton, N.J.

NERC, 1991b, Generating Availability Report, 1986-1990, North American Electric Reliability Council, Princeton, N.J.

NRC, 1991, Generic Environmental Impact Statement for License Renewal of Nuclear Plants (draft report for comment), report NUREG-1437, Vol. 1, U.S. Nuclear Regulatory Commission, Washington, D.C.

Oleson, K.A., 1971, "Methods of Rejecting Waste Heat From Steam electric Power Plants," presented at the 68th Annual Meeting of the American Institute of Chemical Engineers, Houston, Texas. 
Paddock, R.A., and J.D. Ditmars, 1978, "An Assessment of the Once-Through Cooling Alternative for Central Steam Electric Generating Stations," report ANL/WR-78-5, Argonne National Laboratory, Argonne, Ill.

Reiley, M.C., 1992, personal communication, Office of Wastewater Enforcement and Compliance, U.S. Environmental Protection Agency, Washington, D.C.

Stone \& Webster, 1979, "A Survey of Capital Costs of Closed-Cycle Cooling Systems for Steam Electric Power Plants," Proceedings of the American Power Conference, vol. 41, Chicago, Ill.

Stone \& Webster, 1992, Evaluation of the Potential Costs and Environmental Impacis of Retrofitting Cooling Towers on Existing Steam Electric Power Plants that Have Obtained Variances under Section 316(a) of the Clean Water Act, prepared for the Edison Electric Institute, Washington, D.C.

United Engineers \& Constructors, 1974, Heat Sink Design and Cost Study for Fossil and Nuclear Power Plants, report WASH-1360, prepared for U.S. Atomic Energy Commission, Washington, D.C.

United Engineers \& Constructors, 1978, Commercial Electric Power Cost Studies, Vol. 7: Cooling Systems Addendum: Capital and Total Generating Cost Studies, report NUREG0247, U.S. Nuclear Regulatory Commission and U.S. Department of Energy, Washington, D.C.

U.S. Environmental Protection Agency, 1990, "Steam Electric Power Generating Point Source Category," Code of Federal Regulations, title 40, part 423, pp. 727-736.

U.S. Senate, 1991, "Water Pollution Prevention and Control Act of 1991," S. 1081, 102nd Congress, 1st session, May.

U.S. Senate, 1991, "Water Pollution Prevention and Control Act of 1991," S. 1081, 102nd Congress, 1st session, Majority Staff Draft, December 31.

VanKuiken, J.C., et al., 1992, Replacement Energy Costs for Nuclear Electricity-Generating Units in the United States: 1992-1996, report NUREG/CR-4012, Vol. 3, U.S. Nuclear Regulatory Commission, Washington, D.C.; also VanKuiken, J.C., et al., 1992, report ANLAAA-30, Vol. 3, Argonne National Laboratory, Argonne, Ill., Sept.

Veil, J.A., 1993, Impact on the Steam Electric Power Industry of Deleting Section 316(a) of the Clean Water Act: Capital Costs, report ANL/EAIS-4, Argonne National Laboratory, Argonne, Ill., January. 
APPENDIX A:

ALTERNATE CALCULATION OF HEAT RATE INCREASE 


\section{APPENDIX A:}

\section{ALTERNATE CALCULATION OF HEAT RATE INCREASE}

This appendix explains the calculations and methodology used to derive an independent estimate of the increase in heat rate when a once-through cooling system is converted to cooling towers.

\section{A.1 FOSSIL-FUEL STEAM ELECTRIC PLANTS}

The following calculations evaluate the change in heat rate by assuming that a plant with cooling towers is retrofitted with once-through cooling, the reverse of the situation being studied in the main report. This approach was chosen because design criteria were readily available for a closed-cycle system: EPRI (1988) presents detailed design conditions for a pulverized-coal-fired steam electric plant with mechanical-draft cooling towers. The design conditions are given as a function of size (608.7,610.0, or 405.7 MW) and steam conditions (subcritical or supercritical). The following calculations result in an estimate of what the heat rate would be for such a plant if it were operated with once-through instead of closedcycle cooling. The determination of the heat rate for once-through cooling is divided into two separate computations: the first accounts for the difference in the cooling water flow rate, and the second accounts for the change in steam turbine back pressure.

The first step is calculating the required volumetric flow rate for once-through cooling, $Q_{\text {once-through }}$, which is determined from the following equation (based on the heat load of the steam condenser):

$$
Q_{\text {once-through }}=Q_{\text {cooling tower }} \times \Delta T_{\text {cooulng cower }} / \Delta T_{\text {once-through }},
$$

where

$$
\begin{aligned}
Q_{\text {cooling tower }}= & \text { the volumetric flow rate for a cooling tower; } \\
\Delta T_{\text {cooling tower }}= & \text { the temperature difference between the inlet and outlet } \\
& \begin{array}{l}
\text { streams (i.e., the cooling range) from a cooling tower, taken } \\
\text { to be } 25^{\circ} \mathrm{F}(\mathrm{EPRI} 1988) ; \text { and }
\end{array}
\end{aligned}
$$

$$
\begin{aligned}
\Delta T_{\text {once-through }}= & \text { cooling range for a once-through system, taken to be } 10^{\circ} \mathrm{F} \\
& (\text { DOE 1983, Paddock and Ditmars 1978). }
\end{aligned}
$$

The power required to pump the once-through cooling water, $P_{\text {once-through }}(\mathrm{kW})$, is determined by the following:

$$
P_{\text {once-through }}=Q_{\text {once-through }} \times \Delta p_{\text {once-through }} / 60 / \text { Pump Mechanical Efficiency (\%) , }
$$


where $\Delta p_{\text {once-through }}$ is the difference in pump suction and discharge pressures (in psia) and the mechanical efficiency is assumed to be the same as that of the existing pump (approximately 88.6\%). United Engineers \& Constructors (1974) gives typical values for $\Delta p$ for different cooling systems as a function of plant output and plant type (fossil versus nuclear). For these calculations, $\Delta p_{\text {once-through }}$ equals $22 \mathrm{ft} \mathrm{H}_{2} \mathrm{O}$.

The total in-plant power consumption is then modified to account for the fact that the pumping power requirement for once-through cooling is less than that for cooling towers (because of the lower pressure drop). The net plant output is then given by:

$$
\text { Net Plant Output once-through }=\text { Net Plant Output cooling towers }+P_{\text {cooling cower }}-P_{\text {once-through }}
$$

Finally, the effect of the circulating water on the once-through heat rate is given by:



$$
\begin{aligned}
& \text { I Net Plant Output once-through }
\end{aligned}
$$

The above relation shows that the heat rate for once-through cooling will be less than that for cooling towers because of the lower in-plant power consumption. Table A.1 gives the results of the intermediate calculation of the effect of differences in the circulating water flow rate, and Table A.2 summarizes the estimated heat rate values.

The second component that will affect the heat rate is the effect of decreased steam turbine back pressure. The turbine back pressure is a function of the water temperature at the inlet to the steam condenser, with lower temperatures resulting in greater operating capabilities and therefore lower heat rates. Heat rate corrections to account for the lower inlet water temperature are given in United Engineers \& Constructors (1974) and Avallone and Baumeister (1987); these references indicate the correction factor to be on the order of $2 \%$. The heat rate obtained in Equation A.4, which reflects the changed volume of circulating water, is now divided by the back pressure correction factor to arrive at the final estimate of the heat rate. These calculations imply that retrofitting an existing pulverized-coal-fired plant that uses once-through cooling with cooling towers would increase the heat rate by about $2.5 \%$ for subcritical steam operation and by about $2.2 \%$ for supercritical steam operation.

\section{A.2 NUCLEAR STEAM ELECTRIC PLANTS}

Detailed design conditions for a 1,000-MW nuclear boiling-water (BWR) steam electric plant with natural-draft cooling towers are given in DOE (1983). The procedure for calculating the heat rate increase is similar to that for fossil-fuel power plants, except that 


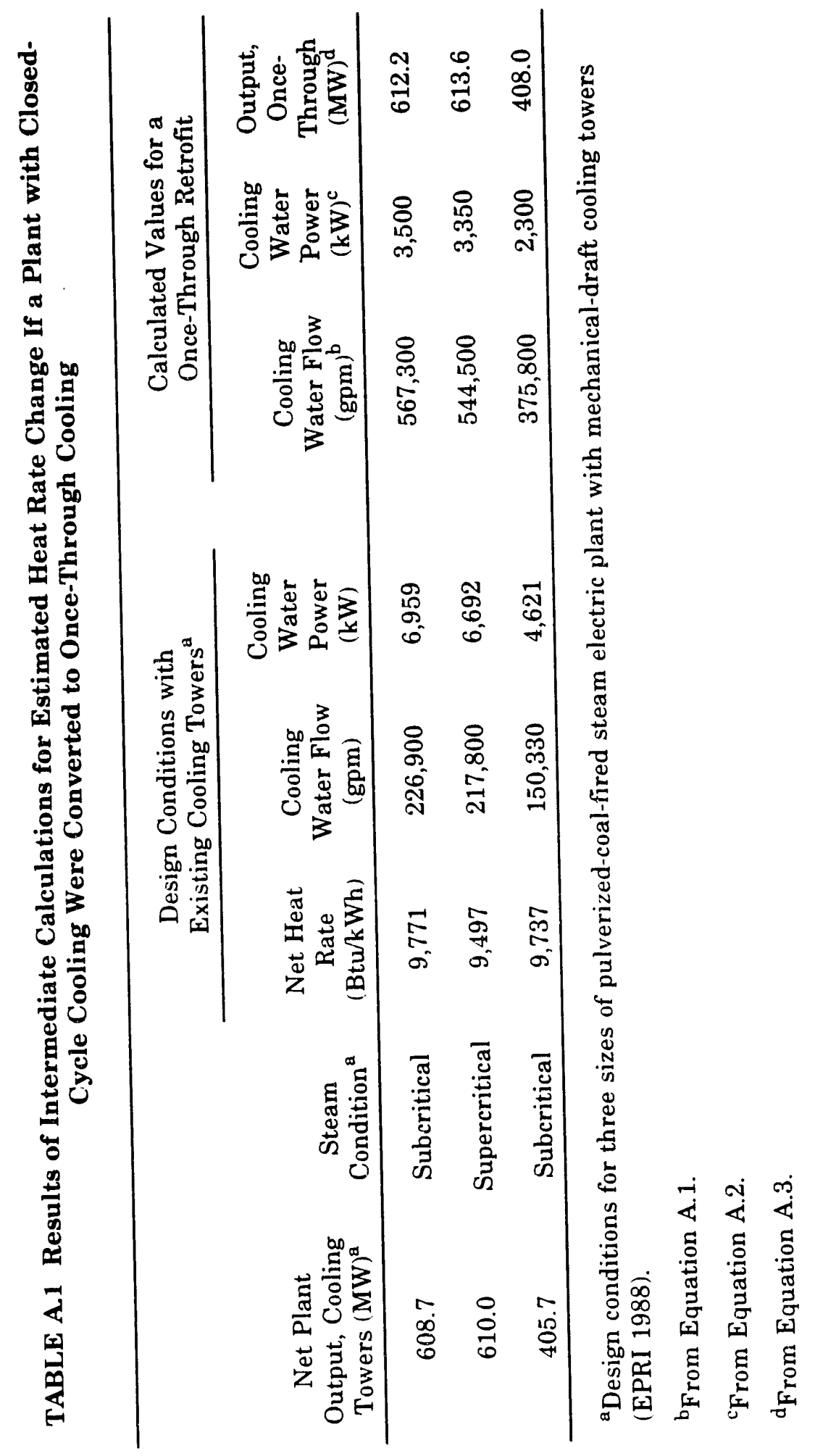




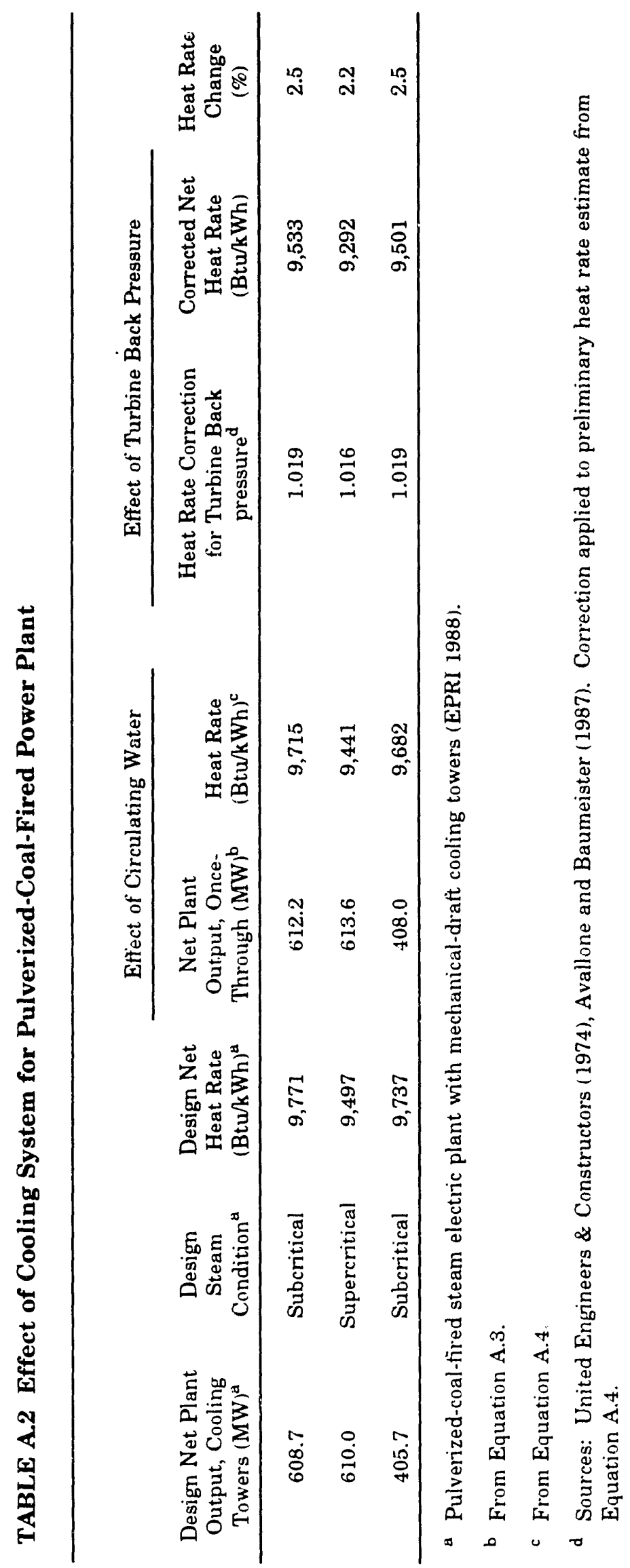


the cooling range of the cooling tower systein, $\Delta T_{\text {cooling towers, }}$ is not given. Instead, it is calculated from the heat load of tice condenser, $q(\mathrm{Btu} / \mathrm{h})$, and the volumetric flow rate, $Q_{\text {cooling towers }}(\mathrm{gpm})$ :

$$
\Delta T_{\text {coolle wowers }}=q / Q_{\text {coollwe nowera }} / 499.8 .
$$

The heat load, $q$, is calculated as follows:

$$
q=(65 \%) \times(\text { Heat Rate } \text { coolung oomens }[B t u / k W h]) \times(1,000,000 \mathrm{~kW}) .
$$

where the $65 \%$ represents the portion of the input heat that becomes waste heat that must be dissipated by the steam condenser. The cooling range for the cooling tower system was determined to be $15^{\circ} \mathrm{F}$.

The design heat rate for the cooling tower system is given as $10,342 \mathrm{Btu} / \mathrm{kWh}$ in DOE (1983), while the computed value for once-through couling is about $10,050 \mathrm{Btu} / \mathrm{kWh}$. This result represents an approximate heat rate increase of $2.8 \%$ for a 1,000 -MW BWR that is retrofitted in response to the loss of a Section $316($ a) variance.

\section{A.3 REFERENCES FOR APPENDIX A}

Avallone, E.A., and T. Baumeister, 1987, Marks'Standard Handbook for Mechanical Engineers, 9th ed., McGraw-Hill Book Co., New York, N.Y., pp. 9-54 to 9-57.

DOE, 1983, Energy Technology Characterizations Handbook: Environmental Pollution and Control Factors, report DOE/EP-0093, U.S. Department of Energy, Washington, D.C.

EPRI, 1988, An Evaluation of Integrated-Gasification-Combined-Cycle and Pulverized-Coal. Fired Steam Plants, report EPRI AP-5950, Electric Power Research Institute, Palo Alto, Calif.

Paddock, R.A., and J.D. Ditmars, 1978, "An Assessment of the Once-Through Cooling Alternative for Central Steam Electric Generating Stations," report ANL/WR-78-5, Argonne National Laboratory, Argonne, Ill.

United Engineers \& Constructors, 1974, Heat Sink Design and Cost Study for Fossil and Nuclear Power Plants, report WASH-1360, prepared for U.S. Atomic Energy Commission, Washington, D.C. 
APPENDIX B:

POWER POOL DESIGNATIONS 


\section{APPENDLX B:}

\section{POWER POOL DESIGNATIONS}

\begin{tabular}{|c|c|c|}
\hline $\begin{array}{l}\text { Power } \\
\text { Pool }\end{array}$ & $\begin{array}{l}\text { NERC } \\
\text { Region }\end{array}$ & Power Pool Composition \\
\hline $1^{a}$ & ECAR & $\begin{array}{l}\text { American Electric Power System, Buckeye Power Inc., Ohio Valley } \\
\text { Electric Corp., Richland Power and Light }\end{array}$ \\
\hline $2^{\mathrm{a}}$ & ECAR & $\begin{array}{l}\text { Central Area Coordination Group, Byron Municipal Light and Water, } \\
\text { Cleveland Division of Light and Power }\end{array}$ \\
\hline 3 & ECAR & Allegheny Power System \\
\hline $4^{\mathrm{a}}$ & ECAR & $\begin{array}{l}\text { Michigan Electric Coordinated Systems, Michigan Municipal } \\
\text { Cooperative Pool, Detroit Public Lighting Dept., Edison Sault Electric } \\
\text { Co., Lansing Board of Water and Light, Michigan Public Power Agency }\end{array}$ \\
\hline $5-6^{\mathrm{a}, \mathrm{b}}$ & ERCOT & Texas Interconnected Systems, associate members of ERCOT \\
\hline $7^{\mathbf{a}}$ & MAAC & $\begin{array}{l}\text { Pennsylvania-New Jersey-Maryland Interconnection, associate } \\
\text { members of MAAC }\end{array}$ \\
\hline $8^{\mathrm{a}}$ & MAIN & Commonwealth Edison Co. \\
\hline $9-10^{a, c}$ & MAIN & $\begin{array}{l}\text { Illinois-Missouri Group (South-Central Illinois Subregion and East } \\
\text { Missouri Subregion of MAIN) }\end{array}$ \\
\hline $11^{\mathrm{a}}$ & MAIN & Wisconsin-Upper Michigan Subregion of MAIN \\
\hline $12^{\mathrm{a}}$ & MAPP & Mid-Continent Area Power Pool (MAPP) \\
\hline 13 & MAPP & Nonmember utilities in the MAPP region \\
\hline $14^{\mathrm{a}}$ & NPCC & New England Power Pool \\
\hline $15^{\mathrm{a}}$ & NPCC & New York Power Pool \\
\hline $16^{\mathrm{a}}$ & SERC & Florida subregion of SERC \\
\hline $17^{\mathrm{a}}$ & SERC & Southern subregion of SERC \\
\hline $18^{a}$ & SERC & Tennessee Valley Authority \\
\hline $19^{\mathrm{a}}$ & SERC & Virginia-Carolinas Subregion of SERC \\
\hline $20^{\mathrm{a}}$ & SPP & Group A (W. Arkansas-Louisiana-Mississippi area of SERC) \\
\hline 21 & SPP & Group B (Oklahoma area of SERC) \\
\hline $22^{\mathrm{a}}$ & SPP & Group C (W. Missouri-Kansas area of SERC) \\
\hline 23,24 & - & $\begin{array}{l}\text { No longer used. Originally covered two additional groups in SPP until } \\
\text { that region was characterized by three groups. }\end{array}$ \\
\hline $25^{\mathrm{a}}$ & WSCC & Northwest Power area of WSCC \\
\hline $26^{\mathrm{a}}$ & WSCC & Arizona-New Mexico area of WSCC \\
\hline $27^{\mathrm{a}}$ & WSCC & California-Nevada area of WSCC \\
\hline 28 & WSCC & Rocky Mountain area of WSCC \\
\hline 29 & - & Alaska Systems Coordinating Council (affiliate NERC member) \\
\hline 30 & - & Hawaii \\
\hline 31 & ECAR & $\begin{array}{l}\text { Cincinnati Gas and Electric Co., Dayton Power and Light Co., } \\
\text { Hamilton Dept. of Public Utilities Electric Division }\end{array}$ \\
\hline 32 & ECAR & $\begin{array}{l}\text { Kentucky Utilities Group, Big Rivers Electric Corp., } \\
\text { Eastern Kentucky Power Cooperative Inc., Henderson } \\
\text { Municipal Power and Light, Louisville Gas and Electric Co., } \\
\text { Owensboro Municipal Utilities }\end{array}$ \\
\hline
\end{tabular}


APPENDIX B (Cont.)

\begin{tabular}{lll}
\hline $\begin{array}{l}\text { Power } \\
\text { Pool }\end{array}$ & $\begin{array}{l}\text { NERC } \\
\text { Region }\end{array}$ & \multicolumn{1}{c}{ Power Pool Composition } \\
\hline 33 & ECAR & $\begin{array}{l}\text { Hoosier Energy Rural Electric Cooperative, Inc., Indianapolis Power } \\
\text { and Light Co., Northern Public Service Co., Public Service Co. of } \\
\text { Indiana, Inc., Southern Indiana Gas and Electric Co., Wabash Valley } \\
\text { Power Assoc. }\end{array}$ \\
\hline
\end{tabular}

a Power pool containing at least one reactor considered in VanKuiken et al. (1992).

b Although the ERCOT region has two components (basically the Texas Utilities Group and the Central and Southwest Group), it is treated as a single power pool because the Texas Interconnected System provides a high level of coordination in planning and operation.

c The two components of the Illinois-Missouri Group are treated as a single pool because of their high level of coordination in planning and operation.

Source: VanKuiken et al. (1992). 


\section{DISTRIBUTION FOR ANL/EAIS-5}

Internal

ANL, Patent Department

K.S. Macal (5)

ANL Technical Publications Services

J. Andrew

J.A. Veil (27)

External

U.S. Department of Energy Office of Scientific and Technical Information (12)

Manager, U.S. Department of Energy Chicago Field Office

ANL-E Libraries

ANL-W Library 

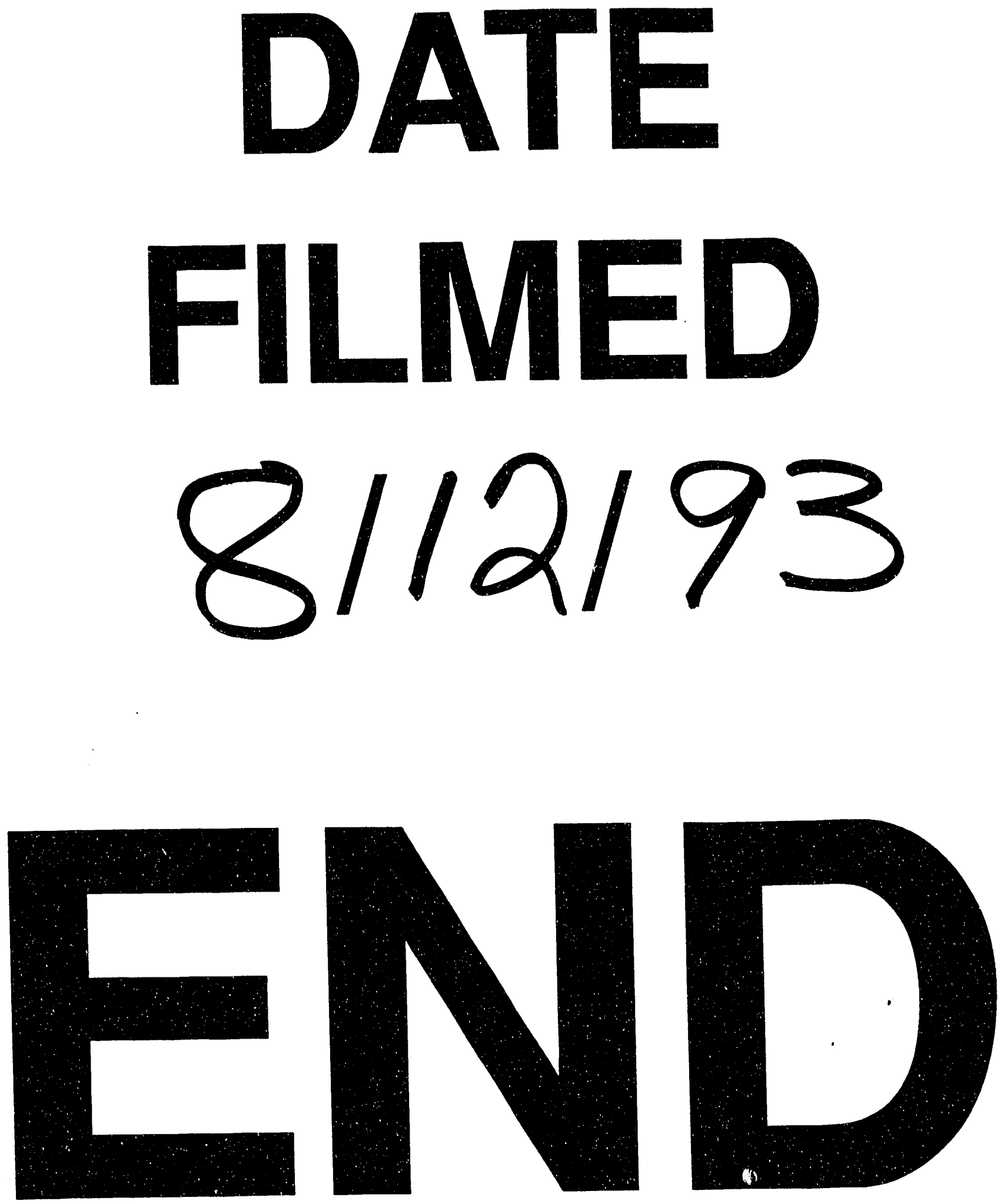
